Jacek Reginia-Zacharski

\title{
Tożsamość bezpieczeństwa przestrzeni Bałkanów Zachodnich w świetle teorii regionalnych kompleksów bezpieczeństwa
}

\section{Regionalne kompleksy bezpieczeństwa jako efekt procesu sekurytyzacji}

Wśród koncepcji, poszukujących interpretacji przestrzeni własnych interesów strategicznych i tożsamości w dziedzinie bezpieczeństwa, poczesne miejsce od pewnego czasu zajmuje „teoria regionalnych kompleksów bezpieczeństwa” (Regional Security Complex Theory, RSCT) ${ }^{1}$. W myśl tej koncepcji bezpieczeństwo definiowane jest przede wszystkim w regionalnych kontekstach geograficznych. Zagrożenia są uznawane za najbardziej prawdopodobne i tak postrzegane (sekurytyzowa$\mathrm{ne})^{2} \mathrm{w}$ bezpośrednim sąsiedztwie.

Podstawa dla teorii sekurytyzacji, rozwijanej przez popularna w ostatnich kilkunastu latach tzw. szkołę kopenhaską jest silnie zakorzenione $\mathrm{w}$ konstruktywizmie przekonanie o konieczności systemowego podejścia do transformacji

${ }^{1}$ B. Buzan, O. Wæver, J. de Wilde, Security. A New Framework for Analysis, Boulder-London 1998, s. 7.

${ }^{2}$ L. Hansen, A case for Seduction? Evaluating the Poststructuralist Conceptualization of Security, „Cooperation and Conflict” 1997, vol. 32, no. 4, s. 369-373. 
konfliktu ${ }^{3}$. Jeden z jej podstawowych obszarów zainteresowania stanowią pytania o sposób transformacji celu w problem, dotyczący bezpieczeństwa (stanowi to istotę konfliktu) oraz kwestie dotyczące dynamiki konfliktu w efekcie procesów sekurytyzacji. W tym rozumieniu konflikt ma swoje źródło w zdefiniowaniu przez jednego $\mathrm{z}$ aktorów sytuacji, jako bezpośrednio zagrażajacej dalszemu istnieniu, przetrwaniu, zagwarantowaniu możliwości realizacji „żywotnych potrzeb” itd. Istotą konfliktu zatem nie jest obiektywnie istniejący stan rzeczy, lecz subiektywne zdefiniowanie swojej pozycji $\mathrm{w}$ systemie (a właściwie jego stworzenie poprzez nazwanie) jako zagrożonej. Bezpieczeństwo zatem posiada, co szkoła kopenhaska zdecydowanie podkreśla, wyłącznie subiektywna naturę: [Nasza - J. R.-Z.] definicja bezpieczeństwa okazuje się wyraźnie konstruktywistyczna w tym sensie, że nie pyta$m y, c z y$ dany problem sam $w$ sobie jest zagrożeniem, ale skupiamy sie na kwestii: kiedy, w jakich warunkach i kto sekurytyzuje problem ${ }^{5}$. Aktor $\mathrm{w}$ sytuacji sekurytyzacji uzasadnia swoje prawa do użycia nadzwyczajnych środków i łamania istniejących norm. W ten sposób poprzez nałożenie na sytuację „etykiety” bezpieczeństwa lub zagrożenia, dana kwestia ulega jakościowej zmianie, stając się tym, czym została określona ${ }^{6}$. Ole Wæver ujmuje problem jeszcze dosadniej, twierdząc, iż bezpieczeństwo nie jest kwestia odnoszqca się

${ }^{3}$ M.C. Williams, Words, Images, Enemies: Securitization and International Politics, „International Studies Quarterly” 2003, vol. 47, no. 4, s. 514-517.

${ }^{4}$ Por. A. Moravcsik, Is Something Rotten in the State of Denmark? Constructivism and European Integration, „Journal of European Public Policy" 1999, vol. 6, no. 4, s. 669-675.

${ }^{5}$ B. Buzan, O. Wæver, Regions and Powers. The Structure of International Security, Cambridge 2004, s. 71.

${ }^{6}$ Ibidem, s. $71-72$. 
do czegoś realnego - wypowiedź sama w sobie jest działaniem. Poprzez stwierdzenie, że coś zostato zrobione [...]. Deklarujac „bezpieczeństwo”, przedstawiciel strony uruchamia konkretny rozwój wydarzeń w danym obszarze, a tym samym przyznaje [swojej stronie - J. R.-Z.] szczególne prawo do wykorzystania wszelkich środków, jakie sq niezbędne dla jego zagwarantowa$n i a^{7}$. Z drugiej strony warto wskazać na proces odwrotny - desekurytyzację, którą Barry Buzan uznaje za optymalna opcję dtugofalowa. Należy ją rozumieć jako proces usuwania z dyskursu łańcuchów istniejqcych zagrożen, przeciw którym musimy podejmować nadzwyczajne środki ${ }^{8}$. Ostatecznie pozwala to na przerwanie sekwencji akcja-reakcja (zagrożenie/obrona) i podjęcie próby powrotu do regularnych relacji społecznych. Tak więc według operacyjnego konstruktywizmu, samo odwołanie się do zagrożenia (zwerbalizowanie) wystarczy, by uruchomić proces samonapędzania się poczucia niebezpieczeństwa (nawet jeśli osąd został przesadzony lub wygenerowany sztucznie) i wzmocnienia świadomości zagrożenia obserwatora poprzez samoodróżnianie od źródła zagrożenia9 ${ }^{9}$ Innymi słowy, zróżnicowanie systemu komunikacyjnego w stanie zagrożenia jest tożsame z utworzeniem samozwrotnego systemu konfliktu, który - na podstawie założenia ogólnej teorii systemów - ma tendencję do kontynuacji i wchodzenia w fazy chroniczne. Zatem konflikt wynika z nieustającej komunikacji zagrożenia, która Wæver i Buzan opisuja jako sekurytyzację $e^{10}$.

${ }^{7}$ O. Wæver, Securitization and Desecuritization, [w:] On Security, ed. R.D. Lipschutz, New York 1995, s. 55.

${ }^{8}$ B. Buzan, O. Wæver, J. de Wilde, op. cit., s. 29.

${ }^{9}$ Por. S. Bernshausen, Th. Bonacker, A Constructivist Perspective on Systemic Conflict Transformation, [w:] The non-linearity of peace processes. Theory and practice of systemic conflict transformation, eds. D. Körppen, N. Ropers, H.J. Giessmann, Opladen 2011, s. 26-27.

${ }^{10}$ B. Buzan, O. Wæver, op. cit., s. 75-76. 
Jednak, co warto podkreślić, o powodzeniu sekurytyzacji nie decyduje wyłącznie podmiot „wypowiadający”, ale także adresat (audytorium) deklaracji bezpieczeństwa. Istotna jest kwestia, czy odbiorca przyjmie, że coś jest egzystencjalnym zagrożeniem dla wspólnych wartości ${ }^{11}$. W taki sposób konflikt staje się przede wszystkim domena komunikacji wewnątrzgrupowej, a jego dwa komponenty - nadawca i odbiorca - i jakość relacji między nimi określają kierunki konfliktu. Nie powinno jednak umykać znaczenie otoczenia konfliktu. Z jednej strony istotnie wpływa na jakość i kierunki komunikacji poprzez normy, koszty podejmowanych decyzji itd. Z drugiej, jak pisano powyżej, konflikt może podlegać sterowaniu i zmierzać ku ewentualnemu zakończeniu - bądź w efekcie realizacji scenariusza negatywnego, bądź w innym przypadku rola czynnika zewnętrznego, jako katalizatora zmiany systemu konfliktowego jest nie do przecenienia. Strony konfliktu muszą mieć pozytywna wizję tego, o co warto zabiegać, często na długotrwałej i bolesnej drodze do transformacji konfliktu. Taka wizja jednak nie może być narzucona z zewnątrz, ale musi być opracowana „organicznie” przez same strony konfliktu ${ }^{12}$. Otoczenie, które może być utożsamiane z „trzecim uczestnikiem”"13, nadal pozostaje istotnym generatorem potencjalnych rozwiązań, trudnych do wypracowania w zamkniętym ścisłym środowisku konfliktu. Wraca tu przekonanie, że rywalizacja pozostaje przede wszystkim domena zmiany, a konstruktywistyczne do niego podejście formułuje postulat przedefiniowania konfliktu i postrzegania go jako szansy na zmianę ${ }^{14}$. Możliwość

${ }^{11}$ B. Buzan, O. Wæver, J. de Wilde, op. cit., s. 31.

${ }^{12}$ S. Bernshausen, Th. Bonacker, op. cit., s. 30-31.

${ }^{13}$ R.J. Fisher, Methods of Third-Party Intervention, Berlin 2001, passim.

${ }^{14}$ I.W. Zartman, G.O. Faure, Lessons for Research, [w:] Escalation and Negotiation in International Conflicts, eds. I.W. Zartman, G.O. Faure, Cambridge 2005, s. 295-297; zob. też I.W. Zartman, Conflict and Resolution: 
fundamentalnej transformacji często wyłania się z chaosu, nieporozumień i konfliktów, a celem powinno być wykorzystanie sytuacji konfliktowej jako momentu, a dokładniej serii momentów, dających szansę przyczynienia się do rozwoju społeczeństw ${ }^{15}$. W tym nieco zaskakującym wnioskowaniu można odnaleźć nawet pobrzmiewające echa koncepcji organicystycznych, jednak ta obserwacja pozwala plasować poglądy konstruktywistyczne w perspektywie optymistycznej, wyrażanej w przekonaniu, że na końcu właściwie konstruowanego procesu znajduje się właśnie rozwój.

$$
* * *
$$

Bezpieczeństwo każdego uczestnika $\mathrm{w}$ regionie jest ściśle powiązane $\mathrm{z}$ bezpieczeństwem innych aktorów regionalnych, co często prowadzi do intensywnej rywalizacji ze słabą bądź żadną sekurytyzacją relacji między regionami ${ }^{16}$. Z drugiej strony względy bezpieczeństwa definiują region, co zresztą wpisuje się we właściwy „szkole kopenhaskiej" postulat badania wielostronnych współzależności. Regiony bezpieczeństwa $\mathrm{w}$ istocie stanowią osobne byty stosunków międzynarodowych, wewnątrz których panują różne zasady systemowe ${ }^{17}$. Istotną rolę

Contest, Cost, and Change, „The Annals of the American Academy of Political and Social Science" 1991, vol. 518, no. 1, s. 11-22.

${ }^{15} \mathrm{~S}$. Bernshausen, Th. Bonacker, op. cit., s. 32.

${ }^{16}$ Więcej zob. A.A. Stein, St.E. Lobell, Geostructuralism and International Politics: The End of the Cold War and the Regionalization of International Security, [w:] Regional Orders. Building Security in a New World, eds. D.A. Lake, P.M. Morgan, University Park 1997, s. 117-124.

${ }^{17}$ B. Buzan, O. Waever, op. cit., s. 44-46; O.F. Knudsen, Post-Copenhagen Security Studies: Desecuritizing Securitization, „Security Dialogue” 2001, vol. 32, no. 3, s. 359-366. Olav F. Knudsen dość ostro krytykuje koncepcję „sekurytyzacji”, uznając ją za bardziej pasującą do realiów 
pełnia tu „państwa buforowe” - podmioty znajdujace się na geograficznych „obrzeżach” regionów bezpieczeństwa ${ }^{18}$. Stanowią one szczególnie wrażliwe obszary z uwagi na rywalizację pomiędzy kompleksami i możliwość transferu z jednego podsystemu do drugiego ${ }^{19}$. Łącząc logikę „kompleksów bezpieczeństwa” z wizją „świata podzielonego na troje” ${ }^{20}$, można postawić hipotezę, iż podmioty „kręgu

zimowojennych aniżeli okresu po $1991 \mathrm{r}$. Wydaje się jednak, że zaznaczenie w koncepcji RSCT zastrzeżenia o różnych narzędziach przydatnych $\mathrm{w}$ analizie relacji w regionach, pozwala sformułować hipotezę, iż sekurytyzacja w pewnych RSCT jest głęboko adekwatna. Szczególnie trafne wydają się wnioski wyciagane w odniesieniu do kręgów industrialnego i przedindustrialnego.

${ }^{18}$ M. Partem, The Buffer System in International Relations, „Journal of Conflict Resolution" 1983, vol. 27, no. 1, s. 5-7.

${ }^{19} \mathrm{~W}$ oparciu o tę koncepcję można analizować przypadek wojny gruzińskiej z 2008 r., gdzie wiele wskazywało, iż Gruzja miała szansę wejścia do „nowego regionalnego kompleksu bezpieczeństwa”, R.D. Asmus, Mała wojna, która wstrzqsnęła światem. Gruzja, Rosja i przeszłość Zachodu, Warszawa 2011; R. Potocki, Wojna sierpniowa, Warszawa 2009, s. 10-15; idem, Wojna sierpniowa: konflikt o granice Zachodu?, [w:] Konflikt kaukaski w 2008 roku, red. nauk. R. Potocki, M. Domagała, P. Sieradzan, Warszawa 2012, s. 278-299.

${ }^{20}$ Koncepcje „trójdzielnego świata” pojawiają się w różnych ujęciach, np. w koncepcjach Roberta Coopera, Alvina i Heidi Tofflerów, Edmunda Wnuka-Lipińskiego, czy na gruncie nauk o bezpieczeństwie Bolesława Balcerowicza, zob.: R. Cooper, Breaking Nations. Order and Chaos in the Twenty-First Century, London 2003; idem, Pękanie granic. Porzqdek $i$ chaos $w$ XXI wieku, Warszawa 2005; A. i H. Toffler, Trzecia fala, Warszawa 2001; iidem, Budowa nowej cywilizacji. Polityka trzeciej fali, Poznań 1996; iidem, Wojna i antywojna, Warszawa 2006; E. Wnuk-Lipiński, Świat międzyepoki: globalizacja, demokracja, państwo narodowe, Kraków 2004; B. Balcerowicz, Teorie, koncepcje wojny (i pokoju) po zimnej wojnie, [w:] Porzadek międzynarodowy u progu XXI wieku. Wizje - koncepcje - paradygmaty, pod red. nauk. R. Kuźniara, Warszawa 2005, s. 469-473. 
poindustrialnego" współtworzą (mega) strefę bezpieczeństwa, charakteryzująca się zauważalnie wysokim poziomem konsolidacji wokół przyjętych zasad, interesów i celów oraz wysoką świadomością wspólnoty, współzależności i dążeniem do harmonizacji stosunków wzajemnych. „Rejonami buforowymi" będą w takim ujęciu obszary zdestabilizowane bądź z wysokim potencjałem destabilizacji ${ }^{21}$, które definiowane sa jako zagrożenia stabilności i trwałości zasad systemowych wewnątrz „kręgu”. Wyznaczanie geograficznych granic i zasięgu systemu oraz próby posłużenia się tym kryterium dla wskazania „buforów” wydają się problematyczne z uwagi na postępującą deterytorializację relacji, interesów i celów. Wydaje się, że przy tej uwadze zastrzeżenia Olava F. Knudsena, dotyczące niestosowalności „teorii sekurytyzacji” do modelu po zimnowojennej organizacji stosunków międzynarodowych - przede wszystkim w odniesieniu do państw i podmiotów „świata pokoju”, tracą na zasadności ${ }^{22}$. Kryterium wskazywania „obszarów buforowych”, ewentualnych „ognisk zapalnych”, czy „rejonów pęknięć" ${ }^{23}$ charakteryzuje bowiem daleko posunięta subiektywność, którą można nazwać specyficzną formą sekurytyzacji.

${ }^{21}$ Por. T. Turmanidze, Buffer States: Power Policies, Foreign Policies and Concepts, New York 2012, s. 44-49.

${ }^{22}$ O.F. Knudsen, op. cit., s. 361-362.

${ }^{23}$ D. Conway, R. Wolfel, Geopolitical globalization. From world system to global city systems, [w:] Globalization's Contradictions: Geographies of Discipline, Destruction and Transformation, ed. D. Conway, N. Heynen, Abington 2006, s. 119-120; S.B. Cohen, Geopolitics: The Geography of International Relations, Lanham 2009, s. 44. Zob. też omówienie koncepcji stref wstrzasów Saula Cohena w: L. Moczulski, Geopolityka. Potega w czasie i przestrzeni, Warszawa 2010; C. Jean, Geopolityka, Warszawa 2005. 


\section{Tożsamość bezpieczeństwa Bałkanów Zachodnich $\mathrm{w} X X \mathrm{w}^{24}$}

Do zakończenia I wojny światowej trudno uznać, że interesujący nas tu obszar miał jakąkolwiek ukształtowaną tożsamość bezpieczeństwa. Można natomiast przyjać, iż ostatnie lata pokoju światowego upłynęły pod znakiem narastania napięcia, którego jednym $\mathrm{z}$ aspektów było zapewne dążenie do trwałego ustalenia samoidentyfikacji strategicznej regio$n u^{25}$. Jeszcze kryzys bośniacki z lat 1908-1909 dobitnie świadczył o niesamodzielności strategicznej regionu, w odniesieniu do którego główne decyzje zapadały poza nim $^{26}$. W świetle RSCT ten okres należałoby uznać za czas pozostawania Bałkanów Zachodnich na pograniczu kompleksów bezpieczeństwa ówczesnych światowych potęg - przede wszystkim Turcji, Austro-Węgier i Rosji ${ }^{27}$. Głos lokalnych podmiotów państwowych, bądź aspirujących do samodzielnego bytu, posiadał dalece mniejsze znaczenie. Wojny bałkańskie z lat 1912-1913 interpretować można jako próbę redefinicji statusu regionu, częściowo udaną ${ }^{28}$. Można przyjąć, iż w wyniku I wojny bałkańskiej Imperium Otomańskie zdecydowanie straciło na znaczeniu jako element kształtujący system bezpieczeństwa

${ }^{24}$ Trzeba pamięć, że termin „Bałkany Zachodnie” powstał na przełomie XX i XXI w. - związany był z procesem akcesyjnym do Unii Europejskiej państw powstałych po rozpadzie Jugosławii oraz Albanii.

${ }^{25}$ M. Kukiel, Dzieje polityczne Europy od rewolucji francuskiej, Londyn-Warszawa 1992, s. 502-504; R.C. Hall, The Balkan Wars 1912-1913. Prelude to the First World War, London-New York 2000, passim; R. Rabka, Batkany 1912-1913, Warszawa 2010, passim.

${ }^{26}$ W. Dobrzycki, Historia stosunków międzynarodowych $w$ czasach nowożytnych 1815-1945, Warszawa 2002, s. 180-187.

${ }_{27} \mathrm{~J}$. Rubacha, Butgarski sen o Bizancjum: polityka zagraniczna Butgarii w latach 1878-1913, Warszawa 2004, s. 364-367.

${ }^{28}$ R. Rabka, op. cit., s. 120-122. 
regionalnego ${ }^{29}$. II wojna bałkańska zaznaczyła się już próbą wyklarowania nowego systemu dystrybucji potęgi w regionie, przy czym te działania (realizowane w scenariuszu orężnym) podjęte zostały przez czynniki rodzime ${ }^{30}$. Wynik tego starcia nie zyskał możliwości utrwalenia się - przede wszystkim z uwagi na wybuch wojny światowej w roku następnym. Nie powinno jednocześnie umykać uwadze to, iż osiagnięta równowaga daleka była od trwałości i stabilności, a kształt sojuszy w pierwszych latach wojny w pewnym stopniu odzwierciedlał tendencje do kwestionowania kształtu tożsamości strategicznej ${ }^{31}$. Dodać też trzeba, że region nie osiagną pełnej suwerenności - wpływy wyżej wspomnianych mocarstw światowych nadal pozostawały silne (jeżeli nie dominujące) ${ }^{32}$. Można przyjaćc, iż okres 1913-1914 stanowił pewnego rodzaju preludium do, mającego nastapić po 1918 r., okresu, gdy region stał się samodzielnym kompleksem bezpieczeństwa.

Osiagnięcie tej sytuacji możliwe było przede wszystkim w wyniku wojennej klęski właściwie wszystkich mocarstw wpływających wcześniej na kształt systemu bezpieczeństwa Bałkanów Zachodnich. Wraz z uzyskaniem szansy na podmiotowość w kształtowaniu własnej tożsamości bezpieczeństwa Królestwo Serbów, Chorwatów i Słoweńców (a od 1929 r. Królestwo Jugosławii) stanęło w obliczu konieczności zmierzenia

${ }^{29}$ J. Heller, British Policy Towards the Ottoman Empire 1908-1914, Abington 1983, s. 73-75.

${ }^{30}$ J.G. Schurman, The Balkan Wars: 1912-1913, London 2008, s. 72 i nast.; H. Bozarslan, The Ottoman Empire, [w:] A Companion to World War I, ed. J. Horne, Oxford 2012, s. 494-495.

${ }^{31}$ R.C. Hall, op. cit., s. 127-129; Z.A.B. Zeman, The Balkans and the Coming of War, [w:] The Coming of the First World War, eds. R.J.W. Evans, H. Pogge von Strandmann, Oxford-New York 2000 (e-book: brak paginacji). Autor nazywa nawet rozpoczęcie I wojny światowej wybuchem „III wojny bałkańskiej".

${ }^{32}$ W. Dobrzycki, op. cit., s. 189-190. 
się z rzeczywistą lub potencjalną (sekurytyzowana) groźba ze strony innych czynników państwowych ${ }^{33}$ - przede wszystkim Włoch ${ }^{34}$ i Węgier ${ }^{35}$. Te przesłanki uzasadniają określenie Bałkanów Zachodnich samodzielnym kompleksem bezpieczeństwa, autonomicznie definiujaccym elementy matrycy identyfikacji strategicznej. W części literatury przedmiotu występuje tendencja do używania raczej terminu subregion. Jest to o tyle uzasadnione, że interesujacy obszar pozostawał elementem składowym szerszego - europejskiego, kompleksu bezpieczeństwa. Istotna (nie rozstrzygając sporu językowego) pozostaje autonomia, czy może lepiej niezależność w decydowaniu o własnym miejscu na strategicznej mapie świata ${ }^{36}$. Zwornik, jakim były wymienione wyżej czynniki integrujace, przestał istnieć w okresie II wojny światowej. Jugosławia zreszta przestała być obszarem, którego losy decydowały się na miejscu. Niemiecka okupacja i realizacja polityki divide et impera spowodowały rozpad całego organizmu i pogłębiajaca

${ }^{33} \mathrm{~W}$. Armstrong, Culture, Continuity and Identity in the Italy-Slovene Border Region, [w:] Culture and Cooperation in Europe's Borderlands, ed. by J. Anderson, L. O’Dowd, Th.M. Wilson, (seria: „European Studies”, vol. 19), Amsterdam-New York 2003, s. 146-148; B. Busch, Shifting Political and Cultural Borders: Language and Identity in Border Region of Austria and Slovenia, [w:] ibidem, s. 127-128; C. Fink, Defending the Rights of Others: The Great Powers, the Jews, and International Minority Protection, Cambridge 2004, s. 269-273.

${ }^{34}$ Więcej zob. T. Maciejewski, Konstytucja Wolnego Miasta Fiume (Rijeka) z 27 sierpnia 1920 r., [w:] Regnare, gubernare, administrare. Prawo i władza na przestrzeni wieków, red. St. Grodziski i A. Dziadzio, Kraków 2012, s. $176-181$.

${ }^{35}$ T. Wituch, Terytoria sporne $w$ Europie po roku 1815, Pułtusk 2001, s. 171-178; M. Tanty, Batkany w XX wieku. Dzieje polityczne, Warszawa 2003, s. 156-158; więcej zob. H. Batowski, Rozpad Austro-Wegier 19141918 (Sprawy narodowościowe i działania dyplomatyczne), Kraków 1980, s. 280 i nast.

${ }^{36}$ M. Tanty, op. cit., s. 210. 
się atrofię strategiczna ${ }^{37}$. Pozwala to na sformułowanie hipotezy o samodzielności strategicznej Bałkanów Zachodnich $\mathrm{w}$ warunkach braku istnienia silnych zewnętrznych biegunów potęgi, które negatywnie wpływałyby na politykę w regionie. Nie pozbawione słuszności wydaje się twierdzenie, że uwarunkowania wewnętrzne przesądzały o długotrwałym zorganizowaniu strategicznym subregionu wzdłuż dwóch osi konfliktowych, które dość trwale definiowały jego konstrukcję i dynamikę. Pierwsza była wynikiem konstelacji konfliktów między Serbami, Chorwatami i Bośniakami; druga koncentrowała się wokót Macedonii, angażując Albanię, Serbię/ Jugostawie, Butgarie i Grecje oraz (okazjonalnie) Turcję ${ }^{38}$. Jako adekwatną analizę cech dynamiki tego obszaru można dodatkowo przytoczyć opinię, iż [ten - J. R.-Z.] subkompleks zawsze charakteryzowat się anarchicznościq oraz zdecentralizowaniem - jednak state wzorce polaryzacji i przyjazni/wrogości z reguty byty trudne do uchwycenia. Bardziej stabilne elementy ulokowane sq na szczeblu lokalnym, natomiast caty subkompleks nie jest zorganizowany $w$ uktadzie „tańcuchowym", jak to ma miejsce w Afryce, ponieważ panstwa (i inni aktorzy polityczni) sq wyjatkowo silnie uwrażliwione na ciagi uwarunkowań wynikajacych dla nich $z$ innych konfliktów ${ }^{39}$. Taka charakterystyka Bałkanów Zachodnich uzasadnia postrzeganie regionu właśnie w kategoriach subkompleksu bezpieczeństwa, w którym tożsamość - jakkolwiek budowana przy silnym udziale rodzimych elementów definiujących - pozostaje w znacznym stopniu funkcją uwarunkowań wyższego

${ }^{37}$ M. Rekść, Jeden kraj, trzy historie. Interpretacje przeszłości w podaytonowskiej Bośni i Hercegowinie, [w:] Bośnia i Hercegowina 15 lat po Dayton. Przeszłość - teraźniejszość - perspektywy. Studia i szkice, pod red. P. Chmielewskiego i S.L. Szczesio, Łódź 2011, s. 382-385.

${ }^{38}$ B. Buzan, O. Waever, op. cit., s. 382.

${ }^{39}$ Ibidem, s. 382-383. 
poziomu (kompleksowego) zorganizowania strategicznego. Przy takim rozumowaniu nasuwa się wniosek o wzroście znaczenia elementu rodzimego w sytuacjach słabnięcia lub równoważenia się wpływów zewnętrznych oraz marginalizacji możliwości samoidentyfikacji subregionu przy wzroście oddziaływania regionu i dominacji jednego bieguna hierarchizującego i porządkującego relacje ${ }^{40}$.

Anegdota o dzieleniu przy użyciu serwetki wpływów na Bałkanach podczas spotkania w Moskwie pomiędzy Winstonem Churchillem a Józefem Stalinem w październiku 1944 r. $^{41}$ dobrze oddaje rzeczywistość strategiczną regionu u schyłku II wojny światowej. Obszar przedwojennej Jugosławii nie był brany pod uwage jako region (czy subregion) obdarzony samodzielnością decyzyjna. Konflikt pomiędzy Jugosławią a Związkiem Radzieckim z lat 1947-1948 doprowadził do wyizolowania wpływów zewnętrznych, bądź przynajmniej ich zniesienia jako czynnika decydującego ${ }^{42}$. Niewykluczone, że za decyzja Josipa Broz-Tity (oprócz względów ideologicznych i personalnych) stało przekonanie o konieczności unikania właczenia Jugosławii do bloku wschodniego w charakterze państwa „pogranicza”. Taka sytuacja właściwie przetrwała do końca lat 80 . XX w. ${ }^{43}$ Wzmocnieniu tej „niezależności” służyło rozwijanie aktywności w tzw. ruchu państw niezaangażowanych.

Podobne zjawiska, które można próbować określać jako szukanie „trzeciej drogi”, dość często można było obserwować

${ }^{40}$ L. Hansen, Security as Practice. Discourse Analysis and the Bosnian War, New York 2006, s. 95-96.

${ }^{41}$ R. Blake, Winston Churchill, Warszawa 2000, passim.

${ }^{42}$ S. Rajak, Yugoslavia and the Soviet Union in the Early Cold War. Reconciliation, Comradeship, Confrontation, 1953-1957, New York 2011, s. 34-37.

${ }^{43}$ L. Hansen, Security as Practice..., s. 154. 
po rozpadzie ZSRR ${ }^{44}$. Nowo powstałe państwa, leżące głównie na obszarach, które przez lata definiowane były jako rubieże kompleksów bezpieczeństwa, usiłowały określać się w nowej rzeczywistości jako niezaangażowane, neutralne itp. ${ }^{45}$ Warto przywołać przykład Białorusi, która na początku lat 90. XX w. jako zasadę konstytucyjną przyjęła (choć raczej nietrwale) neutralnośćc ${ }^{46}$, czy też Ukrainy z jej „polityką wielowektorowości" ${ }^{47}$. Losy Bałkanów Zachodnich, w tym czasie naznaczonym dużą turbulentnościa, potoczyły się innymi torami.

Funkcjonowanie jako „obszaru buforowego" rywalizacji pomiędzy dwoma megakompleksami bezpieczeństwa, i jednocześnie swoistej hybrydy zimnowojennej - marksistowskiego państwa, korzystajacego ze współpracy z Zachodem - stało się na kilkadziesiąt lat jedną z „racji istnienia” Jugosławii. To samo definiowanie strategiczne zaznaczało się zresztą zarówno na płaszczyźnie międzynarodowej, jak i wewnętrznej,

${ }^{44}$ Por. S.P. Huntington, Trzecia fala demokratyzacji, Warszawa 2009, s. 286 (wydanie pierwotne S.P. Huntington, The Third Wave: Democratization in the Late 20th Century, Cambridge 1991, s. 283).

${ }^{45}$ I. Melnykovska, R. Schweickert, T. Kostiuchenko, Balancing National Uncertainty and Foreign Orientation: Identity-Building and the Role of Political Parties in Post-Orange Ukraine, [w:] Elites and Identities in Post-Soviet Space, ed. D. Lane, Abington 2012, s. 138-144.

${ }^{46}$ J. Zaprudnik, Development of Belarusian National Identity and Its Influence on Belarus's Foreign Policy Orientation, [w:] National Identity and Ethnicity in Russia and the New States of Eurasia, ed. R. Szporluk, New York 1994, s. 139-140.

${ }^{47}$ S.M. Birgerson, After the Breakup of a Multi-ethnic Empire: Russia, Successor States, and Eurasian Security, Westport 2002, s. 94 i nast.; L.W. Barrington, Region, Language and Nationality: Rethinking Support in Ukraine for Maintaining Distance from Russia, [w:] Dilemmas of State-led Nation Building in Ukraine, eds. T. Kuzio, P.J. D'Anieri, Westport 2002, s. 133-136; N. Popson, Conclusion: Regionalism and Nation Building in Divided Society, [w:] ibidem, s. 204-205. 
stanowiąc dość szczególne - jednak równocześnie mocne - spoiwo $^{48}$. Już w drugiej połowie lat 80. XX w., która, notabene, zbiegła się ze śmiercią Tity, słabnięcie i rozmywanie się rywalizacji Wschód-Zachód odbiło się na rzeczywistości politycznej Jugosławii zauważalnym wzrostem potencjału destabilizacyjnego.

\section{Bałkany Zachodnie w rzeczywistości pozimnowojennej}

Procesy głębokich przemian geopolitycznych, które w ostatniej dekadzie XX w. stały się udziałem całej Europy Środkowej i Wschodniej, w Jugosławii przybrały szczególnie eksplozywny i ostry charakter. Uwarunkowania tych zjawisk posiadały naturę wielopłaszczyznowa, jednak uzasadnione jest ich grupowanie w dwóch zbiorach - czynników wewnętrznych i zewnętrznych. $\mathrm{O}$ ile te pierwsze posiadaja literaturę olbrzymia, z doskonałymi i głębokimi analizami, to kwestia czynników zewnętrznych $\mathrm{w}$ pewnym stopniu pozostaje w cieniu. Tymczasem w wielu wypadkach ich oddziaływanie (niejednokrotnie niebezpośrednie) posiadało olbrzymie znaczenie dla zmian.

$\mathrm{Na}$ pierwszy plan wysuwa się spostrzeżenie, że z racji szczególnej pozycji, zajmowanej przez Jugosławię w zimnowojennym systemie „równowagi napięć”, dla wyjaśnienia jej pozimnowojennych losów nie daje się zastosować argument o „zdjęciu mecenatu” potęg zewnętrznych. Co najwyżej można pokusić się o stwierdzenie, że wraz z końcem układu zrównoważonego, którego jedną z cech charakterystycznych było pozostawienie Jugosławii w pozycji autonomicznego subkompleksu bezpieczeństwa, zaktywizowały się państwowe

${ }^{48}$ L. Hansen, Security as Practice..., s. 170. 
czynniki regionalne oraz diaspory ${ }^{49}$. W odniesieniu do tego pierwszego argumentu warto zauważyć, że rola czynników regionalnych nie zawsze charakteryzowała się rzeczywista aktywnością ${ }^{50}$. Nierzadko już samo założenie lub przekonanie o potencjalnym zainteresowaniu i ewentualnym przyszłym zaangażowaniu (wsparciu) takiego podmiotu dla aktorów (pretendentów) lokalnych stawało się czynnikiem aktywizujacym $^{51}$. Do pewnego stopnia te nadzieje, ale również rzeczywiste zaangażowanie czynników zewnętrznych, koncentrowały się wokół dwóch historycznie i cywilizacyjnie centrów: pierwszym - wyznaczanym przez spory i konflikty między Serbami, Chorwatami i Bośniakami; drugim - ogniskującym się wokół Macedonii, angażującym Albanię, Serbię i w dalszej perspektywie Bułgarię, Grecję i Turcję ${ }^{52}$. Nie ulega wątpliwości, że ten pierwszy „rdzeń” definiowany był (i jest do dzisiaj) wysokim poziomem wzajemnych wrogości. Co jednak charakterystyczne, układają się one w diadach, które pozostaja wobec siebie w pewnym stopniu wyłaczne - Serbowie/ Chorwaci, Kosowarzy/Serbowie, w Bośni i Hercegowinie (BiH) - bośniaccy Serbowie/Chorwaci/Muzułmanie itd. Konflikty nie nakładają się wzajemnie, co sprawia, że nie występowały tam właściwie żadne, doraźne nawet „koalicje”53. Wraz

${ }^{49}$ M. Klemenčič, M. Žagar, The Former Yugoslavia's Diverse Peoples. A Reference Sourcebook, Santa Barbara 2004, s. 293-295.

${ }^{50}$ D. Wybranowski, Poczatki i pierwsze lata działalności Armii Republiki Bośni i Hercegowiny, [w:] Bośnia i Hercegowina 15 lat..., s. 52-54.

${ }^{51}$ V. Pešić, Ethnic Mobilization in Serbia, Report: „Human and Minority Rights in the Life Cycle of Ethnic Conflicts", Belgrade 2007, s. 6-7; eadem, The War for Ethnic States, [w:] The Road to War in Serbia. Trauma and Catharsis, ed. by N. Popov, New York-Budapest 2000, s. $12-16$.

${ }^{52}$ B. Buzan, O. Waever, op. cit., s. 382.

${ }^{53}$ S.P. Ramet, Explaining the Yugoslav meltdown. A theory about the causes of the Yugoslav meltdown: The Serbian national awakening 
z upadkiem ideologicznego zwornika oraz końcem zbalansowanego układu zimnowojennego, jak też z braku występowania czynnika integrującego $\mathrm{w}$ postaci terytorialnych roszczeń ze strony sąsiadów, część głębokich motywacji, przemawiających za trwaniem państwa, przestała istnieć. Siła uwidocznionych tendencji odśrodkowych - wyraźnie zreszta motywowanych wspomnianymi wcześniej czynnikami zewnętrznymi - istotnie przeważyła słabnące więzi, dotychczas konsolidujące Jugosławię ${ }^{54}$. Otworzyła się tym samym opcja na redefiniowanie wyzwań sekurytyzacyjnych na obszarze rozpadającego się państwa. Część z nich skanalizowała się na obszarze zarysowanych powyżej układów binarnych. Istotne też stało się formułowanie własnych odniesień tożsamościowych, w znacznej mierze odwołujących do mitologizacji, czy to istniejących wcześniej, czy tworzonych doraźnie. Tu adekwatnym przykładem może być przywoływanie „odświeżonych” koncepcji „Wielkiej Albanii”, „Wielkiej Serbii” itd. W poszukiwaniu twardych wyznaczników własnej tożsamości, na które pojawiło się zapotrzebowanie w wyniku nowych procesów sekurytyzacyjnych, przydatne okazały się argumenty etniczne i religijne (wyznaniowe), w okresie zimnowojennym eksponowane słabo lub wcale. Definiowanie tożsamości w aspektach kulturowych, cywilizacyjnych i politycznych dało efekt zarysowania się wyraźnych linii podziału, które ustaliły się na terenach objętych konfliktem ${ }^{55}$. Nie można również pominąc innego zjawiska, jakie najdobitniej było widać przy obserwacji map etnicznych

as a "revitalization movement”, „Nationalities Papers. The Journal of Nationalism and Ethnicity" 2004, vol. 32, no. 4, s. 765-779.

${ }^{54}$ B. Magaš, The Destruction of Yugoslavia: Tracking the Break-up 1980-92, London-New York 1993, s. 288 i nast.

${ }^{55}$ R. Hayden, From Yugoslavia to the Western Balkans. Studies of a European Disunion, 1991-2011, Leiden 2013, s. 7-14. 
obszaru Bośni i Hercegowiny z lat 1992-199556. Trwajaca wojna i migracje z nią związane spowodowały drastyczne „uporządkowanie” rozmieszczenia ludności. $\mathrm{BiH}$, przed rozpoczęciem wojny wyraźnie zsalamandryzowana pod względem rozmieszczenia etnicznego, przekształciła się $\mathrm{w}$ region $\mathrm{z}$ wyodrębnionymi trzema obszarami z dominacją etniczna ${ }^{57}$. Za Erickiem Melanderem ${ }^{58}$ można postawić hipotezę, iż właśnie ten proces w jakimś stopniu przyczynił się do wygaszenia temperatury i dynamiki konfliktu. Wykształcenie się wyraźnych i dużych obszarów z czytelnie zaznaczoną dominantą etniczną uporządkowało także kwestię powiązań między czynnikami lokalnymi a ośrodkami wsparcia zewnętrznego. Ta sytuacja przyczyniła się również do reaktywacji pytania o losy Bośni i Hercegowiny, a w konsekwencji całych Bałkanów Zachodnich, w kontekście przynależności (tożsamości) geostrategicznej59. Właściwie można zaryzykować stwierdzenie, iż pierwsze oznaki kierunku rozwoju sytuacji pojawiły się wcześniej niż w 1995 r., a to za sprawą wyraźnego dookreślenia pozycji Słowenii i Chorwacji ${ }^{60}$. Nie mniej jest to hipoteza niełatwa do obrony, chociażby z uwagi na dość istotne miejsce scenariuszy dezintegracyjnych, jakie formułowane były w odniesieniu

${ }^{56}$ Ibidem, s. 52.

${ }^{57}$ Szczegółowe omówienie tej kwestii zob. S.L. Burg, P.S. Shoup, The War in Bosnia-Herzegovina. Ethnic Conflict and International Intervention, New York 2000, s. 24-35.

${ }^{58}$ E. Melander, The Geography of Fear: Regional Ethnic Diversity, the Security Dilemma and Ethnic War, „European Journal of International Relations” 2009, vol. 15, no. 1, s. 96-97. Melander zauważył, że obszary o silnym wymieszaniu etnicznym są znacznie bardziej podatne na konflikty, podczas gdy pojawienie się wyraźnie dominującego (ilościowo) czynnika sprzyja osiagnięciu równowagi.

${ }^{59}$ R. Hayden, op. cit., s. 97.

${ }^{60}$ Więcej zob. J. Wojnicki, Proces instytucjonalizacji przemian ustrojowych w państwach postjugosłowiańskich, Pułtusk 2007, s. 111-113. 
do regionu $\mathrm{w}$ pierwszej połowie lat 90 . XX w. ${ }^{61}$ Wydaje się, że dopiero decyzje podjęte w Dayton (listopad 1995 r.) stanowiły wyraźny sygnał o przewadze opcji prozachodniej w definiowaniu strategicznej tożsamości BiH. Instalacja IFOR - międzynarodowych sił pod egidą Sojuszu Północnoatlantyckiego - na terenie całego kraju była posunięciem tyle wymuszonym praktyka ${ }^{62}$, co deklaracja na rzecz jego przyszłości. Co warte podkreślenia, w pierwszej fazie wojny w $\mathrm{BiH}$ Stany Zjednoczone powstrzymywały się od istotnego zaangażowania $\mathrm{w}$ działania na rzecz rozwiązania konfliktu ${ }^{63}$. W Waszyngtonie uznawano, że sprawy bałkańskie stanowiły obszar zainteresowania strategicznego Unii Europejskiej i innych organizacji Starego Kontynentu (np. KBWE), który te podmioty miały stabilizować pod auspicjami i przy wsparciu Organizacji Narodów Zjednoczonych $(\mathrm{ONZ})^{64}$. Szczególnie wyraźne to stało się w 1993 r. w związku z zaangażowaniem USA w Somalii i po dyrektywie prezydenckiej PPD-25 z maja

${ }^{61}$ St.I. Griffiths, Nationalism in Central and South-Eastern Europe, [w:] Security and Strategy in the New Europe, ed. C. McInnes, London 1992, s. $61-62$.

${ }^{62}$ Wcześniej właściwie żaden inny ośrodek polityczny nie dał solidnych gwarancji sukcesu w dziedzinie zaprowadzenia pokoju i stabilizacji w regionie, C. Bildt, Peace Journey. The Struggle for Peace in Bosnia, London 1998, s. 44; R. Holbrooke, To End a War, New York 1998, s. 68. O wojskowej roli Stanów Zjednoczonych w BiH zob. R. Cody Phillips, Bosnia-Herzegovina. U.S. Army's Role in Peace Enforcement Operations 1995-2004, [Washington 2005], passim.

${ }^{63}$ S.L. Szczesio, Droga do Dayton - zaangażowanie dyplomacji amerykańskiej w końcowej fazie wojny w Bośni i Hercegowinie, [w:] Bośnia $i$ Hercegowina 15 lat..., s. 178; R.C. Nation, War in the Balkans, 19912002, Carlisle 2003, s. 175-177; J.P. Kaufman, NATO and the Former Yugoslavia. Crisis, Conflict, and the Atlantic Alliance, Lanham 2002, s. $65-68$.

${ }^{64}$ Zob. R. Łoś, Niemcy wobec konfliktu w Bośni i Hercegowinie. Próba stabilizacji, [w:] Bośnia i Hercegowina 15 lat..., s. 161-167. 
$1994 \mathrm{r} .^{65}$ Bałkany zostały uznane za strefę strategicznego zainteresowania Europy i jako takie nie powinny znajdować się w orbicie bezpośredniego zaangażowania USA. W pewnym stopniu korespondowało to ze stanowiskiem europejskim, wyrażonym choćby słowami ministra spraw zagranicznych Luksemburga, Jacquesa Poosa, o wybiciu godziny Europy ${ }^{66}$. Niestety, okazało się, że czynniki europejskie nie były zdolne skutecznie reagować na konflikty o skali i intensywności wojny w Bośni i Hercegowinie. Podobne uwagi można zresztą odnieść do ONZ. Ponurym symbolem tego braku woli i możliwości stały się tragiczne wydarzenia ze Srebrenicy z 1995 r.

Głównymi zewnętrznymi aktorami, dysponującymi potencjalnym wpływem na losy $\mathrm{BiH}$, w tym czasie pozostawały Stany Zjednoczone ${ }^{67}$, NATO (w którym główną rolę odgrywały wcześniej wskazane USA), Unia Europejska (przy czym należy dostrzegać również stanowiska poszczególnych państw zachodnioeuropejskich) i Rosja ${ }^{68}$. Dwie ostatnie opcje okazały się najsłabsze. O Unii i możliwościach europejskich pisano nieco wcześniej, Rosja natomiast (mimo deklarowanej woli) nie posiadała zdolności efektywnego zaangażowania się w zarządzanie konfliktem w $\mathrm{BiH}^{69}$. Warto przypomnieć, iż Federacja Rosyjska dopiero co wygasiła wojnę w Czeczenii, a o jej

${ }^{65} \mathrm{M}$. Aguirre, Humanitarian Intervention \& US Hegemony. A Reconciliation, [w:] Selling US Wars, ed. A. Vanaik, Northampton 2007, s. 197-199; T.G. Weiss, The United Nations and Civil Wars, [w:] Order and Disorder After the Cold War, ed. by B. Roberts, Washington 1995, s. $139-140$.

${ }^{66}$ J. Rupnik, The Balkans as a European question, [w:] The Western Balkans and the EU: "the hour of Europe”, ed. J. Rupnik, (seria: „Chaillot Papers", no. 126), Paris 2011, s. 18-20.

${ }^{67}$ S.L. Szczesio, op. cit., s. 192-195.

68 J.P. Kaufman, op. cit., s. 27.

${ }^{69} \mathrm{P}$. Chmielewski, Konflikty bałkańskie pierwszej połowy lat 90. XX wieku w polityce Kremla, [w:] Bośnia i Hercegowina 15 lat..., s. 220-227. 
słabych możliwościach realizowania strategii zewnętrznych świadczy choćby całkowite fiasko koncepcji „krzyżowych gwarancji bezpieczeństwa" dla Europy Środkowej i Środkowo-Wschodniej ${ }^{70}$. Jedynymi zatem aktorami, posiadajacymi „możliwości”, pozostawały NATO i Stany Zjednoczone. O „woli” politycznej do działania pisano wcześniej. Niemniej jednak europejski i transatlantycki region bezpieczeństwa nie mogły sobie pozwolić na bezczynność. W kategoriach RSCT można to wyrazić jako przesłanki przeciwko potraktowaniu Bałkanów Zachodnich jako samodzielnego subregionu bezpieczeństwa i postawienie na scenariusz izolacji konfliktów bez interwencji na rzecz ich zakończenia lub wyhamowania. Dla Europy niedopuszczalne było przejście konfliktu w Bośni i Hercegowinie w fazę chroniczną i zgoda na funkcjonowanie regionu $\mathrm{w}$ charakterze rozsadnika anarchii ${ }^{71}$. Wydaje się, że rozwój sytuacji w Somalii, z której w 1995 r. ostatecznie wycofały się siły międzynarodowe, musiał silnie oddziaływać na procesy decyzyjne $\mathrm{w}$ państwach zachodnioeuropejskich i Stanach Zjednoczonych ${ }^{72}$. Z drugiej strony czynnikiem trudnym do przecenienia (choć też niełatwym do oszacowania) był nacisk opinii publicznej, która dość jednoznacznie domagała się skutecznych rozwiązań. Tu istotne znaczenie dla

${ }^{70}$ R. Zięba, Członkostwo Polski w Unii Europejskiej a stosunki polsko-rosyjskie, [w:] Wybrane aspekty wptywu członkostwa państw Europy Środkowo-Wschodniej na stosunki ze wschodnimi państwami ościennymi, red. M. Zdanowicz, A. Doliwa-Klepacka, Białystok 2009, s. 114-115; J. Kaczmarek, NATO $w$ systemie bezpieczeństwa świata, Wrocław 1998, s. 184185; R. Zięba, Bezpieczeństwo europejskie lat 90. Potrzeba nowego ujęcia problemu, [w:] Bezpieczeństwo państw Europy. Koncepcje i problemy lat 90., pod red. B. Łomińskiego, Katowice 1997, s. 22-23.

${ }^{71}$ B. Buzan, O. Waever, op. cit., s. 430.

${ }^{72}$ J. Reginia-Zacharski, Wojna domowa $w$ Somalii, [w:] R. Łoś, J. Reginia-Zacharski, Wspótczesne konflikty zbrojne, Warszawa 2010, s. 171; E. Drew, On the Edge. The Clinton Presidency, New York 1994, s. 157-158. 
intensyfikacji nacisku publicznej opinii i mediów miały informacje o masakrze w Srebrenicy ${ }^{73}$.

$\mathrm{W}$ tej warstwie zreszta, co warte odnotowania, splatały się argumenty o proweniencji właściwie realistycznej, oparte na przekonaniu o konieczności interwencji dla zbudowania i gwarantowania europejskiego bezpieczeństwa, z podejściem konstruktywistycznym. W tym drugim, poszanowanie praw człowieka - w tym przede wszystkim prawa do życia i do pokoju - stawało istotnym elementem w procesie budowania europejskiej tożsamości w warunkach rzeczywistości pozimnowojennej. Nieco trywializując, można ująć ten pogląd jako postulat konieczności „wypierania barbarzyństwa przez cywilizację". W zawężonej formie interpretowano te wyzwania w kategoriach sprzeczności, czy też ścierania się „rasizmu i faszyzmu” $\mathrm{z}$, integracją i cywilizacją"74. W dyskursie europejskim właśnie ten pierwszy „zestaw” postrzegany był po zakończeniu „zimnej wojny", jako główne zagrożenie dla ładu Starego Kontynentu. Efektem tego „spięcia” były słowa Billa Clintona, komentujace rozwiązania przyjęte w Dayton, czyli decyzję o bezpośredniej interwencji w Bośni i Hercegowinie i - w konsekwencji - włączenia tego kraju do europejskiego kompleksu bezpieczeństwa. Prezydent USA lapidarnie ują to, mówiąc o interwencji zbrojnej, że była to stuszna i właściwa rzecz do zrobienia, [...] nasze amerykańskie wartości i interesy wymagały tego zaangażo$w$ nnia $^{75}$. Obok niewatpliwych inspiracji z zakresu geostrategii, silnie w stanowisku polityków Zachodu wybrzmiewały również elementy aksjologiczne. Można nawet przyjąć, że stanowiły one wyraźną dominantę w argumentacji.

${ }^{73}$ R. Łoś, Wojna w Bośni i Hercegowinie (1992-1995), [w:] R. Łoś, J. Reginia-Zacharski, op. cit., s. 304-305.

${ }^{74}$ L. Hansen, Security as Practice..., s. 128.

${ }^{75}$ Clinton's Words on Mission to Bosnia: 'The Right Thing to Do', ,The New York Times", 28 XI 1995; zob. też E. Drew, op. cit., s. 140. 
Jeszcze silniej motywacje, odwołujące się do zasad humanitarnych, zostały podniesione w przypadku wojny przeciwko Serbii z 1999 r. $^{76}$ Wiele jest racji w stwierdzeniu, iż jakkolwiek NATO wygrato konflikt oraz odniosto informacyjny sukces, odbyto sie to znacznym kosztem $i$ stato sie źródłem wielu problemów ${ }^{77}$. Wspomniane „koszty i problemy” zaznaczyły się dość szybko na dwóch płaszczyznach. Po pierwsze, zbrojna interwencja przeciwko Serbii, mimo eksponowania praw człowieka, jako głównego motywu akcji, spotkała się z pewnymi protestami społeczeństw państw europejskich, chociaż ich rozmiary były stosunkowo niewielkie. Znacznie poważniejsze konsekwencje przyniosły rozbieżności pomiędzy sojusznikami co do sposobu prowadzenia wojny. Założenie o priorytecie minimalizacji ryzyka strat własnych niewątpliwie stało się jednym z głównych uwarunkowań taktyki przyjętych przez gen. Wesleya Clarka ${ }^{78}$, jednak sposób doboru celów wywoływał głębokie animozje ${ }^{79}$. Część badaczy utrzymuje nawet, że decyzja o rozpoczęciu powietrznej wojny przeciwko Serbii i jej przebieg nadwyrężyły kohezję Sojuszu Północnoatlantyckiego, jak też napięły (i tak już niełatwe) relacje z Federacją Rosyjska ${ }^{80}$. Zgodzić

${ }^{76}$ P. Sheets, Air War Over Serbia, [w:] Lessons from Kosovo: The KFOR Experience, ed. L. Wentz, Washington 2002, s. 99-100.

${ }^{77}$ P. Combelles Siegel, Operation Allied Force: The Media and the Public, [w:] ibidem, s. 188.

${ }^{78}$ M. Ignatieff, Virtual War, Toronto 2000, s. 42.

${ }^{79}$ W.K. Clark, Waging Modern War. Bosnia, Kosovo, and the Future of Combat, New York 2002, s. 224-225.

${ }^{80}$ P. Latawski, M.A. Smith, The Kosovo Crisis and the Evolution of Post-Cold War European Security, Manchester-New York 2003, s. 108-110; H.H. Perritt Jr., The Road to Independence for Kosovo. A Chronicle of the Ahtisaari Plan, New York 2010, s. 110. O słabości rosyjskich możliwości oddziaływania strategicznego przed rokiem 2000 zob. B. Lo, The Securitization of Russian Foreign Policy under Putin, [w:] Russia between East and 
się trzeba z tymi opiniami, jednak nie powinno umykać uwadze, że działania rozpoczęły się miesiąc po podsumowaniu jubileuszowego szczytu NATO w Waszyngtonie, na którym stworzono doktrynalne podstawy funkcjonowania Sojuszu w nowej roli. W roku 1999 Rosja wydawała się na tyle słaba, że - jako czynnik, mogący wstrzymywać ewentualną decyzję o uruchomieniu operacji „Allied Force” - nie była poważnie brana pod uwagę. Niemniej jednak warto zwrócić uwagę na to, że decyzja o rozpoczęciu akcji zbrojnej obciążona była ryzykiem z powodu braku autoryzacji Rady Bezpieczeństwa $\mathrm{ONZ}^{81}$. Zakończenie operacji powietrznej NATO w czerwcu 1999 r. oraz przyjęcie przez Radę Bezpieczeństwa rezolucji nr 1244 (10 czerwca) ${ }^{82}$ nie wprost sankcjonowało wcześniejszą akcję zbrojną poprzez uznanie jej skutków.

Niezależnie od ostatecznych konsekwencji, można postawić hipotezę, iż tzw. świat zachodni gotowy był na podjęcie dość wyraźnego ryzyka dla osiagnięcia efektu w postaci włączenia kolejnego fragmentu dawnej Jugosławii do własnej sfery strategicznej (RSC), bądź przynajmniej wyłączenia Kosowa $\mathrm{z}$ autonomicznego subkompleksu bezpieczeństwa ${ }^{83}$.

West. Russian Foreign Policy on the Threshold of the Twenty-First Century, ed. G. Gorodetsky, Abington-New York 2003, s. 12-13.

${ }^{81}$ M. Waldenberg, Rozbicie Jugostawii. Jugostowiańskie lustro międzynarodowej polityki, Warszawa 2005, s. 379.

${ }^{82}$ United Nations. Security Council, S/RES/1244 (1999), 10 June 1999, Resolution 1244 (1999). Adopted by the Security Council at its 4011th meeting on 10 June 1999. Zob. też: The Kosovo Conflict and International Law. An Analytical Documentation 1974-1999, ed. H. Krieger, Cambridge 2001, s. 337; J. Singh, Problem of Ethnicity: Role of United Nations in Kosovo Crisis, Chandigarh 2008, s. 173-176; M. Spernbauer, EU Peacebuilding in Kosovo and Afghanistan: Legality and Accountability, Leiden 2012, s. 48-49.

${ }^{83}$ E.R. Kavalsky, Identity of peace: framing the European security identity of the EU, [w:] European Identity. Theoretical Perspectives and Empirical Insights, eds. I.P. Karolewski, V. Kaina, Berlin 2006, s. 102-103. 
Powodów tej skłonności z pewnością było wiele, jednak warto zwrócić uwagę na wymiar długofalowy. Właściwie kwestia kosowska z lat 1998-1999 wpisuje się w zdecydowanie szerszą perspektywę, której zarania szukać należy na początku lat 90. XX w. Można postawić kolejną hipotezę: u schyłku „zimnej wojny" dostrzeżono na Zachodzie szansę na przesunięcie granicy oddziaływania strategicznego na Bałkanach Zachodnich na wschód. Istotnym elementem takiej strategii stało się „granie” na rozpad Jugosławii lub przynajmniej „życzliwa neutralność" wobec tego procesu. Jesienią 1991 r. Komisja Arbitrażowa (tzw. Komisja Badintera) uznała, że Socjalistyczna Federacyjna Republika Jugosławii znajduje się w stanie rozpadu, tym samym potwierdzając zasadność i prawomocność przyjętego kursu ${ }^{84}$. Jeszcze w grudniu 1991 r. Republika Federalna Niemiec, jako pierwsze państwo, uznała Słowenię i Chorwację za niepodległe państwa, przenosząc tym samym problem do dziedziny politycznej i tworząc nową rzeczywistość międzynarodowa. Jednocześnie dyplomacja niemiecka wzmogła naciski na inne państwa europejskie, by uczyniły to samo ${ }^{85}$. W następnych miesiącach dokonali tego członkowie Wspólnoty Europejskiej, Stany Zjednoczone i szereg innych krajów. W maju 1992 r. nowe państwa zostały członkami Narodów Zjednoczonych ${ }^{86}$. Równocześnie do ONZ przyjęto Bośnię

${ }^{84}$ Prawo międzynarodowe. Materiaty do studiów, pod red. B. Wierzbickiego, Białystok 2008, s. 150-151.

${ }^{85}$ H.M. Mey, Germany, NATO and the War in the Former Yugoslavia, „Comparative Strategy” 1993, vol. 12, no. 2, s. 239-245; J. Wojnicki, op. cit., s. 113.

${ }^{86}$ United Nations. General Assembly, A/RES/46/238, 22 May 1992, Resolution Adopted by the General Assembly. Admission of the Republic of Croatia to membership in the United Nations; United Nations. General Assembly, A/RES/46/236, 22 May 1992, Resolution Adopted by the General Assembly. Admission of the Republic of Slovenia to membership in the United Nations. Zob. też J. Wojnicki, op. cit., s. 128-136. 
i Hercegowinę $e^{87}$. Proces rozpadu Jugosławii toczył się dalej - 8 kwietnia 1993 r. do ONZ przystapiła Macedonia ${ }^{88}$.

O ile w Bośni i Hercegowinie zrealizował się najgorszy scenariusz - zawierajacy $\mathrm{w}$ sobie trzyletnia, wyniszczająca wojnę i akty ludobójstwa - to z perspektywy Belgradu, ale też państw zachodnich, najpoważniejszym wyzwaniem w sferze aksjologicznej był problem Kosowa. Serbowie najsilniej w tym przypadku sięgali do argumentacji naznaczonej „prawami historycznymi”, dla Zachodu zaś wsparcie muzułmańskich Albańczyków przeciwko chrześcijańskim (choć prawosławnym) Serbom, u schyłku naznaczonych eskalowana obawa przed islamem lat 90. XX w., zapewne nie było pozbawione znaczących dylematów. Wymowę tego ostatniego argumentu nieco osłabiał fakt, iż w Waszyngtonie i Londynie, czyli głównych ośrodkach nastawionych na interwencję zbrojna, rządzili liberałowie i socjaldemokraci, jednak z perspektywy społeczeństw motywacje nie były oczywiste. Być może tym należy tłumaczyć tak silne eskalowanie czynnika motywującego w postaci praw człowieka, co w pewnej mierze stało się powodem określenia operacji „Allied Force” pierwszą nowoczesną „interwencją humanitarną". Mimo tego, że koszty polityczne decyzji o rozpoczęciu wojny powietrznej przeciwko Jugosławii okazały się stosunkowo niewielkie, to ryzyko w fazie przedimplementacyjnej musiało być kalkulowane jako istotne. Wydaje

${ }^{87}$ United Nations. General Assembly, A/RES/46/237, 22 May 1992, Resolution Adopted by the General Assembly. Admission of the Republic of Bosnia and Hercegovina to membership in the United Nations. Zob. również J. Wojnicki, op. cit., s. 139-144.

${ }^{88}$ United Nations. General Assembly, A/RES/47/225, 8 April 1993, Resolution Adopted by the General Assembly. Admission of the of the State whose application is contained in document A/47/876-S/25147 to membership in the United Nations. Macedonia została przyjęta jako former Yugoslav Republic of Macedonia. Zob. też J. Wojnicki, op. cit., s. 137-138. 
się, że względy geostrategiczne okazały się w tym przypadku przesądzające. Bowiem ostateczne efekty (oceniane z perspektywy niemal ćwierćwiecza) procesu dekonstrukcji Jugosławii i włączania do zachodniego (europejskiego lub transatlantyckiego) kompleksu bezpieczeństwa kolejnych elementów obszaru Bałkanów Zachodnich wyglądają imponująco. Można przyjać, że wszystkie państwa regionu znalazły się ostatecznie w obszarze strategicznego oddziaływania Zachodu, bądź jako integralna część RSC w wyniku członkostwa w NATO i/lub Unii Europejskiej, bądź jako kandydat do nich. Taka sytuacja właściwie stanowi całkowite novum w nowoczesnych stosunkach międzynarodowych, a jej stabilność należy oceniać jako charakteryzującą się znaczną trwałością.

\section{Konkluzje}

Jeśli pokusić się o podsumowanie powyższych rozważań, na plan pierwszy wysuwa się wniosek o szczególnych „momentach”, w jakich otwierało się „okno możliwości” samodzielnego strategicznego określenia się Bałkanów Zachodnich. Nawet pobieżna analiza dwudziestowiecznych losów tego regionu przekonuje, że podjęcie działań na rzecz samodefiniowania strategicznego było możliwe właściwie w dwóch przypadkach - drastycznego osłabnięcia lub zaniku potęg tradycyjnie decydujacych o dystrybucji potęgi w regionie (okres 1918-1940) oraz równoważenia się wpływów potęg zewnętrznych, przy jednoznacznie zdefiniowanym lokalnym ośrodku władzy (okres 1947-1989). Pozostałe okresy zaznaczały się latami chaosu, anarchii i przemocy zbrojnej narodów Bałkanów Zachodnich, fazą quasi-uporządkowania i, ostatecznie, wejściem dominującej potęgi aspirującej do włączenia regionu we własną strefę strategicznego wpływu lub inaczej 
- do regionalnego kompleksu bezpieczeństwa. Ten ostatni etap naznaczony jest silnie eksponowanym elementem aksjologicznym, co wydaje się tym łatwiejsze, że - jak pisano - następuje po okresie dekonstrukcji (wojny, przemocy zbrojnej, czystek etnicznych itd.). To „uporządkowanie” i włączenie w stabilną sferę wartości do pewnego stopnia posiada charakter kompleksowy i determinujący. Trudna do akceptacji byłaby sytuacja, w której „wartości” implementowane są fragmentarycznie. Możliwe tu są dwa scenariusze: jednorazowego włączenia całego obszaru do RSC lub (co stało się udziałem Bałkanów Zachodnich) realizacji „modelu kroczacego”. Ten ostatni poniekąd wymuszony był „przenoszeniem się” ognisk konfliktowych, które można inaczej nazwać obszarami dekonstrukcji. Nie da się obronić teza, iż to zjawisko było w całości inspirowane przez państwa zachodnie, jednak niektóre elementy rozwoju sytuacji politycznej i wojskowej niewątpliwie zyskiwały większe lub mniejsze wsparcie. Na marginesie warto zauważyć, iż nasuwają się pewne analogie z „kryzysem ukraińskim" z pierwszej połowy 2014 r., choć w tym przypadku inspirująca rola Federacji Rosyjskiej wydaje się raczej oczywista. Generowanie „obszarów dekonstrukcji” poprzez działania dywersyjne i wsparcie elementów antypaństwowych miało otworzyć możliwości pojawienia się czynnika zewnętrznego w charakterze dostawcy bezpieczeństwa i „wartości”, a następnie umożliwić dokonanie przesunięć strategicznych (rozszerzenia własnego RSC).

Bałkany Zachodnie w ostatnim ćwierćwieczu weszły na drogę właściwie bez precedensu. Mimo wcześniejszych prób, europejskie i transatlantyckie kompleksy bezpieczeństwa (lub modele zorganizowania strategicznego) przed latami 90. XX w. nie były $\mathrm{w}$ stanie rozciagnać swojego zasięgu na omawiany obszar. Uruchomiony w warunkach rozpadu państwa jugosłowiańskiego proces, choć jeszcze, jak się wydaje, niedokończony, 
charakteryzuje się sporą solidnością i trwałym potencjałem. Wynikają one w znacznej mierze z faktu, iż oba systemy bezpieczeństwa (transatlantycki i europejski) oparte sa na dość rygorystycznym podejściu do sfery wartości. Wcześniejsze reżimy międzynarodowe $\mathrm{w}$ zdecydowanie mniejszym stopniu podnosiły postulat implementacji warstwy normatywnej, przez co ich trwałość okazywała się mniejsza. 